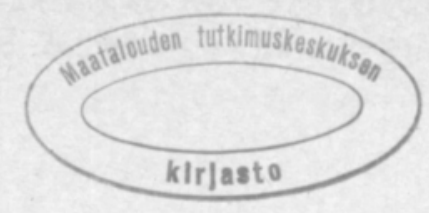

\title{
Kasvuolojen ja lannoituksen vaikutus siemenperunan sadontuottokykyyn ja sadon laatuun
}

\author{
EERO VARIS \\ Hankkijan kasvinjalostuslaitos, Anttilan koetila, Hyrylä
}

Saapunut 8.4.1974

The effects of growing conditions and manuring on the yield capacity of seed
potatoes and on the subsequent crop quality

EERo VARIS

Plant Breeding Institute of Hankkija, Experimental Farm Anttila, Hyrylä, Finland

\begin{abstract}
Trials were carried out at the Hankkija Plant Breeding Institute in the 1960 's to investigate the effects of climate, soil and plant nutrients on the yield capacity and quality of seed potatoes.

The effects of growing conditions and fertilizer practices on the seed potato quality were small compared with those of cultivars and diseases.

Temperature sum and precipitation for seed potato were negatively correlated, latitude positively with starch content of the subsequent crop.

Humus and clay soils showed some positive effects compared with sandy soil. A high level of calcium and phosphorus in the soil had a positive effect, a high $\mathrm{pH}$ and a high content of potassium a negative one on the yield capacity of seed potato.

The timing of the harvest was not significant, although the trend was in favour of an earlier harvest.

Of plant nutrients, $\mathrm{N}, \mathrm{P}, \mathrm{Mg}$, and $\mathrm{Mn}$ showed positive effects. The effect of $\mathrm{K}$ was dependent on the $\mathrm{K}$ rate used. $\mathrm{Ca}$ had no significant effects.

Starch content of the seed tubers showed some positive effects on the yield capacity and on the starch content of the crop.

The $\mathrm{N}$ and $\mathrm{P}$ contents of the seed tubers were positively correlated with subsequent tuber yield and with percentage of large tubers.
\end{abstract}

Siemenperunan käyttöarvoon vaikuttavat 1) terveys, 2) kasvuolot ja viljelytekniikka sekä 3) varastointi ja siemenen käsittely. Tärkeimpinä näistä pidetään yleensä terveyttä ja varastointia (IRITANI 1967). Kasvuolojen vaikutuksia on kuitenkin myös todettu. Useat tutkijat ovat osoittaneet kasvukauden korkean lämpötilan ja siihen yleensä liittyvän kuivuuden heikentävän siemenperunan laatua (Zogg ym. 1949, Wenzl ja Demel 1950, Went 1959, KozLOWSKA 1960, 1963, UlRich ym. 1963, Bocz 1965). Maalajin vaikutusta on 
runsaasti tutkittu varsinkin Pohjoismaissa. Yleensä on todettu suolla tuotetun siemenperunan olevan hiukan, tosin usein merkityksettömän vähän hiekkamaan perunaa elinvoimaisempaa (Witte 1923, Osvald 1929, Saloheimo 1934, Vesikivi 1936, 1938, 1939, Lunden 1950). Keskieurooppalaisissa tutkimuksissa on puolestaan keskijäykät maat todettu yleensä paremmaksi siemenperunan kasvualustaksi kuin hietamaat (KLAPP 1930, 1936, PfFFfer 1956, STOTTMEISTER 1958).

Lannoituksen vaikutuksia on tutkittu eniten typen ja fosforin osalta. Typen vaikutus on yleensä todettu pieneksi (Volkart 1948, KRÜGER 1951, HofferBert ja Putlitz 1956, Pfeffer 1959, Schepers ym. 1969). Lähinnä kasvuston alkukehitys on ollut rehevämpi, mutta merkittäviä satoeroja on todettu ainoastaan heikoissa kasvuoloissa. Sen sijaan runsaan fosforilannoituksen edullisesta vaikutuksesta siemenperunan laatuun ovat tutkijat vakuuttuneempia (DENSCH 1930, Schoene 1937, Klapp 1951, Brandt ja Sessous 1953, Vogt 1953, Wünscher 1953, Hofferbert 1954, Fleischel 1957, Alten ym. 1960, Gericke 1960, Fischnich ja PÄtzold 1961). Schepers ym. (1969) eivät todenneet Hollannin olosuhteissa fosforin eikä liioin kalin vaikutusta merkitseväksi. Jotkut tutkijat ovat todenneet runsaan kalilannoituksen heikentävän siemenperunan arvoa (Hofferbert ja Putlitz 1956). Myös kalin puuttuessa siemenperunan kasvukyky heikkenee (KLAPP 1951).

Selostettavassa tutkimuksessa esitetään yhteenveto niistä Hankkijan kasvinjalostuslaitoksen Anttilan koetilalla suoritetuista tutkimuksista, joissa pyrittiin selvittämään kasvutekijöiden vaikutusta siemenperunan arvoon Suomen olosuhțeissa. Tutkimuksen kohțeina olivat säätekijät, maaperä sekä erilaiset lannoitusyhdistelmät.

Selostettavan tutkimukseen kuuluu kaikkiaan viisi erilaista aineistoa:

1. Viljelijöiltä koottu peruna-aineisto 1961.

2. Maalajin, lannoituksen ja korjuuajan vaikutus $1963-64$.

3. Kaliumin ja magnesiumin vaikutus 1968-70.

4. Kalsiumin ja mangaanin vaikutus $1968-70$.

5. NPK-lannoituksen vaikutus $1966-71$.

Useimpia aineistoja on jo käsitelty aikaisemmissa julkaisuissa ja ne selostetaan lyhyesti kirjallisuusviittauksineen tulosten esittelyn yhteydessä. Kaikki koemateriaali saatiin vastaavista lannoitus- ym. tutkimuksista käyttämällä niiden sato tässä selostettavien siemenperunatutkimusten kylvösiemeneksi.

Kaikki kokeet suoritettiin aitosavipohjaisella, hyvässä kasvukunnossa olevalla multamaalla.

Tulosten tilastollisessa käsittelyssä käytettiin varianssianalyysejä ja multiregressioanalyysejä, jotka laskettiin Keskusosuusliike Hankkijan ATK-osastolla. Tulosten tilastollista merkitsevyyttä on ilmaistu țavalliseen tapaan.

\section{Aineisto 1. Viljelijöiltä koottu peruna-aineisto 1961}

Aineisto käsitti yhteensä 1161 näytettä Jaakko-, K. Yrjö V-, Vesijärvi- ja "Sekalaiset»-lajikkeița, jotka kerättiin maan eri puolilta syksyllä 1960 (VARIS 
1970). Näytteet varastoitiin samaan kellariin ja niillä perustettiin keväällä 1961 lajikkeittain vertailevat satoisuuskokeet cubic-lattice-menetelmää käyttäen (Cochran ja Cox 1960). Ruutu käsitti 25 yksilöä, kerranteita oli 3.

Siemenerien välisiin sato- ja laatueroihin vaikuttavia tekijöitä selvitettiin lineaarisilla multiregressioanalyyseillä, joissa selittäjinä olivat:

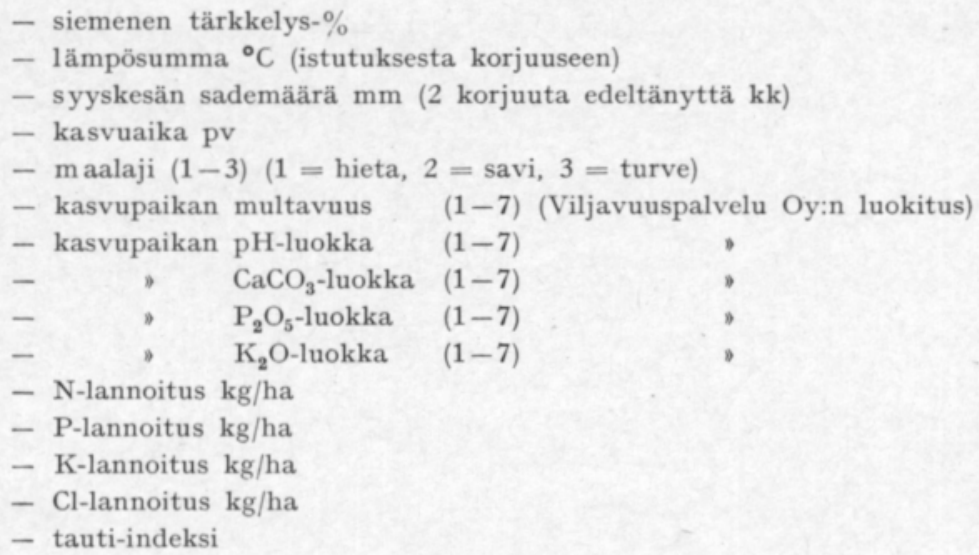

Lajikkeiden välisten satoerojen poistamiseksi käytettiin $0-1$ muuttujia. Tässä tapauksessa lajiketekijöitä oli 3 .

Käytettyjen tekijöiden muodostamisesta, niiden vaihtelun laajuudesta ja keskiarvoista on tehty aikaisemmin selkoa (VARIS 1970).

\section{Mukulasato}

Mukulasadon suhteen multiregressioanalyysi antoi $90 \%$ :n merkitsevyystasolla Taulukossa 1 esitetyn tuloksen.

Taulukko 1. Multiregressioanalyysi viljelijäin perunanäytteiden sadontuottokykyyn vaikuttavista tekijöistä $(\mathrm{n}=1161)$.

Table 1. Multiple regression analysis of factors affecting the yielding capacity of farmers' seed potato samples.

\begin{tabular}{|c|c|c|c|c|}
\hline $\begin{array}{l}\text { Selittäjä } \\
\text { Variable }\end{array}$ & b & $\mathbf{r}$ & $\mathrm{R}^{2}$ & $\begin{array}{l}\text { kumul. } \\
\text { cumul. }\end{array}$ \\
\hline Tauti-indeksi - Disease-index ..... & -0.071 & -0.459 & & 0.145 \\
\hline Lajike - Cultivar 2 ............... & -9.660 & -0.472 & & \\
\hline Lajike - Cultivar 1 ................ & -6.572 & -0.393 & & 0.380 \\
\hline Lajike - Cultivar 3 ................ & -4.305 & -0.334 & & \\
\hline Tärkkelys- $\%$ - Starch content ... & 0.430 & 0.133 & & 0.394 \\
\hline $\mathrm{CaCO}_{3}$-luokka - $\mathrm{CaCO}_{3}$-class $\ldots .$. & 0.561 & 0.095 & & \\
\hline pH-luokka $-p H$-class .............. & -0.568 & -0.093 & & 0.406 \\
\hline $\mathrm{K}_{2} \mathrm{O}$-luokka $-\mathrm{K}_{2} \mathrm{O}$-class $\ldots \ldots \ldots . .$. & -0.425 & -0.091 & & 0.400 \\
\hline $\mathrm{P}_{2} \mathrm{O}_{5}$-luokka $-\mathrm{P}_{2} \mathrm{O}_{5}$-class $\ldots \ldots \ldots . .$. & 0.385 & 0.056 & & \\
\hline
\end{tabular}

$\mathrm{K}=40.36$ 
Mallin selitysaste oli vain $41 \%$, mutta tämänkaltaisissa aineistoissa harvoin päästäänkään suurempaan tarkkuuteen. Matemaatțisen satovaihtelun suuruus $(4 \sigma)$ oli kokonaisuudessaan $26.77 \mathrm{tn} /$ ha. Eniten satoeroja selvițtivät lajikemuuttujat (58\% selvitetystä osasta) ja taudit $(36 \%)$. Siemenen kasvuolosuhdetekijöistä tuli malliin mukaan maaperän $\mathrm{pH}-, \mathrm{Ca}-, \mathrm{P}_{2} \mathrm{O}_{5}-$ ja $\mathrm{K}_{2} \mathrm{O}$-luokka, jotka yhteensä lisäsivät mallin selitysastetța $\left(\mathrm{R}^{2}\right) 3 \%$ pH:n ja kalsiumin vaikutus oli vastakkainen, joten niiden vaikutus käytännössä usein kumoutunee. Maan fosforipitoisuuden vaikutus oli positiivinen, kaliumpitoisuuden negatiivinen. Siemenen tärkkelyspitoisuudella oli positiivinen vaikutus, jonka suuruus oli myös vähäinen, $3 \%$.

Tärkkelyspitoisuus

Sadon tärkkelyspitoisuuteen vaikuttàvista tekijöistä regressioanalyysi antoi Taulukossa 2 esitetyn mallin.

Taulukko 2. Multiregressioanalyysi tärkkelyspitoisuuteen vaikuttavista tekijöistä viljelijäin aineistossa.

Table 2. Multiple regression analysis of factors affecting the starch content from farmers' seed potato samples.

\begin{tabular}{|c|c|c|c|}
\hline $\begin{array}{l}\text { Selittäjä } \\
\text { Variable }\end{array}$ & b & $\mathbf{r}$ & $\mathrm{R}^{2} \begin{array}{l}\text { kumul. } \\
\text { cumul. }\end{array}$ \\
\hline Lajike - Cultivar 2 .............. & -1.35 & -0.411 & \\
\hline Lajike - Cultivar 3 ............... & -0.43 & -0.207 & 0.164 \\
\hline Lajike - Cultivar 1 ............... & -0.52 & -0.199 & \\
\hline Tauti-indeksi - Disease-index ..... & -0.0021 & -0.092 & 0.178 \\
\hline $\begin{array}{l}\text { Tärkkelys- } \%-\text { Starch content } \ldots \\
\text { Lämpösumma } 10^{\circ} \mathrm{C}\end{array}$ & 6.42 & 0.125 & 0.189 \\
\hline Temperature sum $10^{\circ} \mathrm{C} \ldots \ldots \ldots \ldots$ & -0.0060 & -0.091 & \\
\hline Sademäärä - Precipitation ....... & -0.0012 & -0.056 & 0.201 \\
\hline
\end{tabular}

$K=14.6$

Mallin selitysaste oli vain $20 \%$.

Tärkkelyspitoisuuden matemaattinen kokonaisvaihtelu oli $3.8 \%$-yksikköä. Sadon tärkkelyspitoisuuden vaihtelusta selittivät eniten lajikkeet $(82 \%$ selvitetystä osasta). Taudit lisäsivät mallin selitysastetta $7 \%$. Siemenen kasvuolosuhteista oli merkitystä lämpösummalla ja sademäärällä, joilla molemmilla oli negatiivinen vaikutus. Yhteensä näiden osuus oli $6 \%$. Tärkkelyspitoisuus lisäsi myös mallin selitysastetta, tosin vain $5 \%$.

Kun lämpösumma ja sademäärä korreloituivat vahvasti leveysasteeseen, kokeiltiin myös leveysastetta selittäjänä. Se korvasi nämä molemmat tekijät ja lisäsi mallin selitysastetta $10 \%$ :lla.

Aineisto 2. Maalajin, lannoituksen ja korjuuajan vaikutus 1963-64

Anttilan koetilalla Jaakko- ja Vesijärvi-lajikkeilla järjestetyistä kokeista (VARIS 1970) otettiin 2. ja 3. koevuoden jälkeen siemen eri koejäsenten sato- 
tason mittaamiseksi (2 koetta). Kokeet järjestettiin vuosina 1963-64 vaillinaista lattice-menetelmää käyttäen. Koeruudussa oli 50 yksilöä ja kerranteita 4. Varianssianalyysin tulokset mukulasadosta, tärkkelyspitoisuudesta ja lajittelujakautumasta on esitetty Taulukossa 3.

Taulukko 3. Varianssianalyysi maalajin, lannoituksen ja korjuuajan vaikutuksesta Jaakon ja Vesijärven siemenen sadontuottokykyyn ja sadon laatuun.

Table 3. Analysis of variance of the effects of soil, manuring and time of harvest on the yielding capacity of Jaakko and Harbinger seed potatoes and on the subsequent crop quality.

\begin{tabular}{|c|c|c|c|c|}
\hline $\begin{array}{l}\text { Tekijä } \\
\text { Factor }\end{array}$ & $\begin{array}{c}\text { Mukulasato } \\
\text { Tuber yield } \\
\text { tn/ha }\end{array}$ & $\begin{array}{c}\text { Tärkkelys } \\
\text { Starch } \\
\text { content } \\
\%\end{array}$ & $\begin{array}{c}\text { Isot } \\
\text { mukulat } \\
\text { Large } \\
\text { tubers } \\
\%\end{array}$ & $\begin{array}{c}\text { Pienet } \\
\text { mukulat } \\
\text { Small } \\
\text { tubers } \\
\%\end{array}$ \\
\hline A. Vuosi - Year & $* * *$ & *** & ns & *** \\
\hline 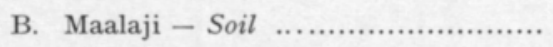 & ns & $* * *$ & $* * *$ & $* * *$ \\
\hline C. Lannoitus - Manuring ................... & $(*)$ & ns & ns & ns \\
\hline D. Korjuuaika - Time of harvest ....... & ns & ns & ns & ns \\
\hline E. Lajike - Cultivar ..................... & $* * *$ & $* * *$ & $* * *$ & $* * *$ \\
\hline AB & $* * *$ & $* * *$ & $(*)$ & $* * *$ \\
\hline AC & $\left({ }^{*}\right)$ & ns & $* * *$ & ns \\
\hline AD & ns & ns & ns & ns \\
\hline AE & $* * *$ & $* * *$ & $* * *$ & $* * *$ \\
\hline ВC & ns & $(*)$ & ns & ns \\
\hline BD & ns & ns & ns & ns \\
\hline ВE & ns & ns & $* * *$ & *** \\
\hline CD & ns & ns & ns & .ns \\
\hline CE & $(*)$ & ns & ns & ns \\
\hline DE & $(*)$ & ns & ns & ns \\
\hline
\end{tabular}

Maalaji

Mukulasadossa ei ollut keskimäärin eroja maalajien välillä (Taulukko 4). Vuosittain maalajit sijoittuivat eri järjestykseen (AB). Savimaalla tuotettu siemenperuna antoi muita paremman tärkkelyspitoisuuden molempina vuosina. V. 1964 myös turvemaan siemenperuna tuotti paremman tärkkelyspitoisuuden kuin hietamaan peruna.

Savimaan siemen tuotti muita vähemmän isoja mukuloita. Kun sato oli kuitenkin hyvä, on mukuloita täytynyt muodostua enemmän kuin muissa koejäsenissä. Lievää vuotuista ja lajikkeiden välistä vaihtelua todettiin (AB, BE). Savimaan siemen tuotti myös eniten pieniä mukuloita. Ero oli merkitsevä kuitenkin vain v. 1963 (AB) ja Vesijärvi-lajikkeella (AD). 
Taulukko 4. Maalajin vaikutus siemenperunan sadontuottokykyyn ja sadon laatuun.

Table 4. The effects of soil type on the yielding capacity of seed potatoes and on the subsequent crop quality.

\begin{tabular}{|c|c|c|c|c|}
\hline $\begin{array}{l}\text { Maalaji } \\
\text { Soil type }\end{array}$ & $\begin{array}{c}\text { Mukulasato } \\
\text { Tuber yield } \\
\text { tn/ha }\end{array}$ & $\begin{array}{c}\text { Tärkkelys } \\
\text { Starch } \\
\text { content } \\
\%\end{array}$ & $\begin{array}{c}\text { Isoja } \\
\text { mukuloita } \\
\text { Large } \\
\text { tubers } \\
\%\end{array}$ & $\begin{array}{c}\text { Pieniä } \\
\text { mukuloita } \\
\text { Small } \\
\text { tubers } \\
\%\end{array}$ \\
\hline Hieta - Finesand ......................... & 26.88 & 16.1 & 38 & 10 \\
\hline Savi - Clay ................................. & 27.23 & 16.4 & 33 & 12 \\
\hline Turve - Peat .............................. & 27.22 & 16.2 & 37 & 10 \\
\hline Suurin ero - Greatest difference .......... & 0.35 & 0.3 & 5 & 2 \\
\hline PME - L.S.D. $(5 \%)$..................... & ns & 0.2 & 3 & 1 \\
\hline
\end{tabular}

\section{Lannoitus}

Mukulasadon suhteen oli 0-lannoitus muita huonompi (Taulukko 5). Lannoituksen yhdysvaikutuksista kävi selville, että koejäsen IV oli v. 1963 paras, v. 1964 huonoin (AC). Lajikkeiden reagoinnissa oli sikäli eroa, että Jaakko näytti hyötyvän enemmän runsaasta N-lannoituksesta kuin Vesijärvi (CE).

Tärkkelyspițoisuudessa ei keskimäärin ollut eroa, mutta karjanlannalla lannoitettu siemenperuna (V) antoi savi- ja turvemaalla alhaisen tärkkelyspitoisuuden. Tässä koesarjassa turvemaa oli runsaskalinen.

Isojen mukuloiden määrässä ei myöskään ollut keskimäärin eroa, mutta tulos erosi eri vuosina toisistaan (AC). V. 1963 runsaalla typellä lannoitettu siemen (IV) tuotti muita vähemmän isoja mukuloita. Kun samalla sato oli hyvä, se viittaa runsaaseen mukuloiden määrään. Pienten mukuloiden määrässä ei ollut eroja missään olosuhteissa.

Taulukko 5. Lannoituksen vaikutus siemenperunan sadontuottokykyyn ja sadon laatuun. Table 5. The effects of fertilizer applications on the yielding capacity of seed potatoes and on the subsequent crop quality.

\begin{tabular}{|c|c|c|c|c|}
\hline $\begin{array}{l}\text { Lannoitus } \\
\text { Manuring }\end{array}$ & $\begin{array}{c}\text { Mukulasato } \\
\text { Tuber yield } \\
\text { tn } / \mathrm{ha}\end{array}$ & $\begin{array}{c}\text { Tärkkelys } \\
\text { Starch } \\
\text { content } \\
\%\end{array}$ & $\begin{array}{c}\text { Isoja } \\
\text { mukuloita } \\
\text { Large } \\
\text { tubers } \\
\%\end{array}$ & $\begin{array}{c}\text { Pieniä } \\
\text { mukuloita } \\
\text { Small } \\
\text { tubers } \\
\%\end{array}$ \\
\hline (0) & 26.38 & 16.3 & 37 & 11 \\
\hline II (N 75, P 50, Ksulf 125) $\ldots \ldots \ldots \ldots \ldots$ & 27.41 & 16.2 & 37 & 11 \\
\hline III (N 75, $\mathrm{P} 50, \mathrm{Kcl} 125) \ldots \ldots \ldots \ldots$ & 27.37 & 16.2 & 36 & 11 \\
\hline IV (N 150, P 50, Ksulf 125) ............ & 27.43 & 16.3 & 35 & 11 \\
\hline V $\quad(\mathrm{Kl} F . M .40 \mathrm{tn}, \mathrm{P}$ 50) $\ldots \ldots \ldots \ldots \ldots$ & 26.97 & 16.1 & 35 & 11 \\
\hline Suurin ero - Greatest difference ........... & 1.05 & 0.2 & 2 & 0 \\
\hline 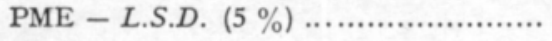 & 0.95 & ns & ns & ns \\
\hline
\end{tabular}


Nostoaika

Siemenperunan korjuuaika ei vaikuttanut merkitsevästi mihinkään tutkittuun ominaisuuteen, joskin suunta oli aikaisemman korjuun eduksi (Taulukko $6)$.

Taulukko 6. Korjuuajan vaikutus siemenperunan sadontuottokykyyn ja sadon laatuun. Table 6. The effects of time of harvest on the yielding capacity of seed potatoes and on the subsequent crop quality.

\begin{tabular}{|c|c|c|c|c|}
\hline $\begin{array}{l}\text { Korjuuaika } \\
\text { Time of harvest }\end{array}$ & $\begin{array}{c}\text { Mukulasato } \\
\text { Tuber yield } \\
\text { tn/ha }\end{array}$ & $\begin{array}{c}\text { Tärkkelys } \\
\text { Starch } \\
\text { content } \\
\%\end{array}$ & $\begin{array}{c}\text { Isoja } \\
\text { mukuloita } \\
\text { Large } \\
\text { tubers } \\
\%\end{array}$ & $\begin{array}{c}\text { Pieniä } \\
\text { mukuloita } \\
\text { Small } \\
\text { tubers } \\
\%\end{array}$ \\
\hline 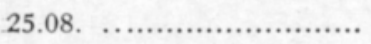 & 27.32 & 16.2 & 36 & 11 \\
\hline 13.09. & 26.90 & 16.2 & 37 & 11 \\
\hline Ero - Difference ............. & 0.42 & 0.0 & 1 & 0 \\
\hline
\end{tabular}

Aineisto 3. Kaliumin ja magnesiumin vaikutus 1968-70

Tähän koesarjaan saatiin siemen yhdistetystä K- ja Mg-kokeesta 1967-69 (VARIS 1972). Jälkitestauksen 3-vuotinen koesarja järjestettiin vuosina 196870 blokki-menetelmällä. Koeruutu käsitti 50 yksilöä, kerranteita oli 4 . Lajike oli Realta.

Kalilannoituksen vaikutus ei ollut tilastollisesti merkitsevä (Taulukot 7 ja 8).

Taulukko 7. Varianssianalyysi $\mathrm{K}-$ ja Mg-lannoituksen vaikutuksesta siemenperunan sadontuottokykyyn ja sadon laatuun.

Table 7. Analysis of variance of the effects of $K$ and $M g$ application rates on the yielding capacity of seed potatoes and on the subsequent crop quality.

\begin{tabular}{lccc}
\hline Tekijä & Mukulasato & Tärkkelys & Lajittelujakautuma \\
Factor & Tuber yield & Starch content & Size distribution \\
& tn/ha & $\%$ & $\%$ \\
\hline
\end{tabular}

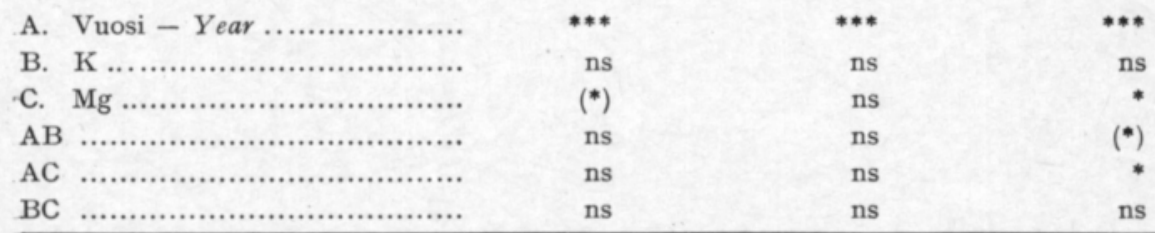


Taulukko 8. Kalilannoituksen vaikutus siemenperunan sadontuottokykyyn ja sadon laatuun. Table 8. The effects of $K$ application rates on the yielding capacity of seed potatoes and on the. subsequent crop quality.

\begin{tabular}{lcccc}
\hline $\begin{array}{l}\text { Lannoitus } \\
\begin{array}{l}\text { Treatment } \\
\mathrm{kg} / \mathrm{ha}\end{array}\end{array}$ & $\begin{array}{c}\text { Mukulasato } \\
\text { Tuber yield } \\
\mathrm{tn} / \mathrm{ha}\end{array}$ & $\begin{array}{c}\text { Tärkkelys } \\
\text { Starch } \\
\text { content } \\
\%\end{array}$ & $\begin{array}{c}\text { Isoja } \\
\text { mukuloita } \\
\text { Large } \\
\text { tubers } \\
\%\end{array}$ & $\begin{array}{c}\text { Pieniä } \\
\text { mukuloita }\end{array}$ \\
\hline \\
$\begin{array}{l}\text { Small } \\
\text { tubers } \\
\%\end{array}$
\end{tabular}

Mg-lannoitus vaikutti lievästi sekä satoon että mukulakokoon (Taulukot: 7 ja 9$)$.

Taulukko 9. Mg-lannoituksen vaikutus siemenperunan sadontuottokykyyn ja sadon laatuun. Table 9. The effects of $\mathrm{Mg}$ application rates on the yielding capacity of seed potatoes and on the subsequent crop quality.

\begin{tabular}{|c|c|c|c|c|}
\hline $\begin{array}{l}\text { Lannoitus } \\
\text { Treatment } \\
\mathrm{kg} / \mathrm{ha}\end{array}$ & $\begin{array}{c}\text { Mukulasato } \\
\text { Tuber yield } \\
\text { tn/ha }\end{array}$ & $\begin{array}{c}\text { Tärkkelys } \\
\text { Starch } \\
\text { content } \\
\%\end{array}$ & $\begin{array}{c}\text { Isoja } \\
\text { mukuloita } \\
\text { Large } \\
\text { tubers } \\
\%\end{array}$ & $\begin{array}{c}\text { Pieniä } \\
\text { mukuloita } \\
\text { Small } \\
\text { tubers } \\
\%\end{array}$ \\
\hline 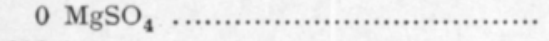 & 28.71 & 15.7 & 48 & 4 \\
\hline 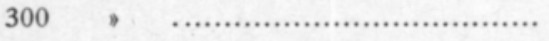 & 30.39 & 16.0 & 51 & 3 \\
\hline 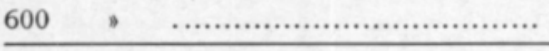 & 30.20 & 15.7 & 51 & 4 \\
\hline Suuri ero - Greatest difference ............. & 1.68 & 0.3 & 3 & 1 \\
\hline PME - L.S.D. $(5 \%$ ) ...................... & 1.70 & ns & 3 & 3 \\
\hline
\end{tabular}

Keskinkertainen Mg-lannoitus näytti tuottavan parhaan tuloksen. Sadon lisäys perustui mukulakoon suurenemiseen, tosin ei jokavuotiseen (AC). Myös. tärkkelyspitoisuus osoitti nousevaa suuntaa $300 \mathrm{~kg}: n \mathrm{MgSO}_{4}$-määrää käytettäessä. KMg-yhdysvaikutukset (BC) eivät olleet merkitseviä.

Aineisto 4. Kalsiumin ja mangaanin vaikutus 1968-70

Tässä 3-vuotisessa monitekijäkokeessa oli seuraavat koejäsenet:

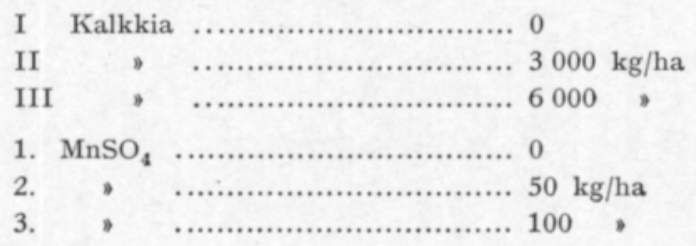


Koejäsenten sadolla perustettiin vuosina $1968-70$ vertaileva siemenerien koe blokki-menetelmällä. Koeruudussa oli 50 yksilöä, kerranteita 4. Lajike oli Realta.

Taulukko 10. Varianssianalyysi Ca- ja Mn-lannoituksen vaikutuksesta siemenperunan sadontuottokykyyn ja sadon laatuun.

Table 10. Analysis of variance of the effects of $\mathrm{Ca}$ and $\mathrm{Mn}$ application rates on the yielding capacity of seed potatoes and on the subsequent crop quality.

\begin{tabular}{|c|c|c|c|}
\hline $\begin{array}{l}\text { Tekijä } \\
\text { Factor }\end{array}$ & $\begin{array}{c}\text { Mukulasato } \\
\text { Tuber yield } \\
\text { tn/ha }\end{array}$ & $\begin{array}{c}\text { Tärkkelys } \\
\text { Starch } \\
\text { content } \\
\%\end{array}$ & $\begin{array}{c}\text { Lajittelu- } \\
\text { jakautuma } \\
\text { Size } \\
\text { distribution } \\
\%\end{array}$ \\
\hline 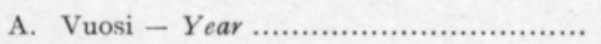 & $* * *$ & $* * *$ & $* * *$ \\
\hline B. Mn & * & ns & ns \\
\hline C. $\mathrm{Ca}$ & ns & ns & ns \\
\hline АВ & ns & ns & $(*)$ \\
\hline AC & $*$ & ns & $* * *$ \\
\hline ВC & ns & ns & ns \\
\hline
\end{tabular}

Kalkitus ei vaikuttanut merkitsevästi siemenen sadontuottokykyyn eikä sadon laatuun (Taulukot 10 ja 11).

Taulukko 11. Ca-lannoituksen vaikutus siemenperunan sadontuottokykyyn ja sadon laatuun. Table 11. The effects of Ca application rates on the yielding capacity of seed potatoes and on the subsequent crop quality.

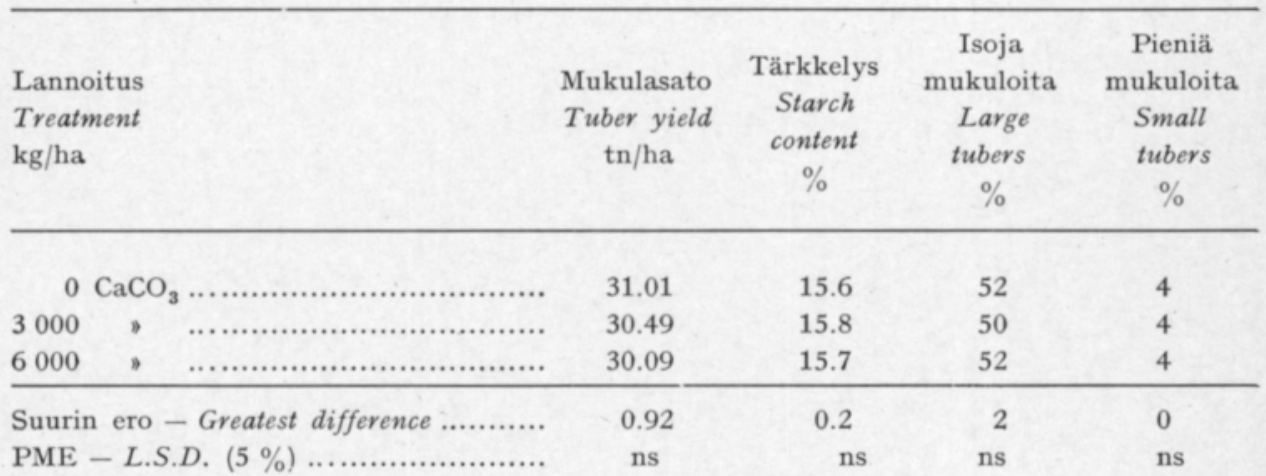

Mukulasadossa oli lievä aleneva suunta, mikä oli selvä varsinkin vuonna 1968 (AC). Tärkkelyspitoisuudessa oli lievä nouseva suunta.

Siemenperunan Mn-lannoitus lisäsi näissä koeolosuhteissa satoa 1.31 tn/ha (Taulukot 10 ja 12). 
Taulukko 12. Mn-lannoituksen vaikutus siemenperunan sadontuottokykyyn ja sadon laatuun. Table 12. The effects of Mn application rates on the yielding capacity of seed potatoes and on the subsequent crop quality.

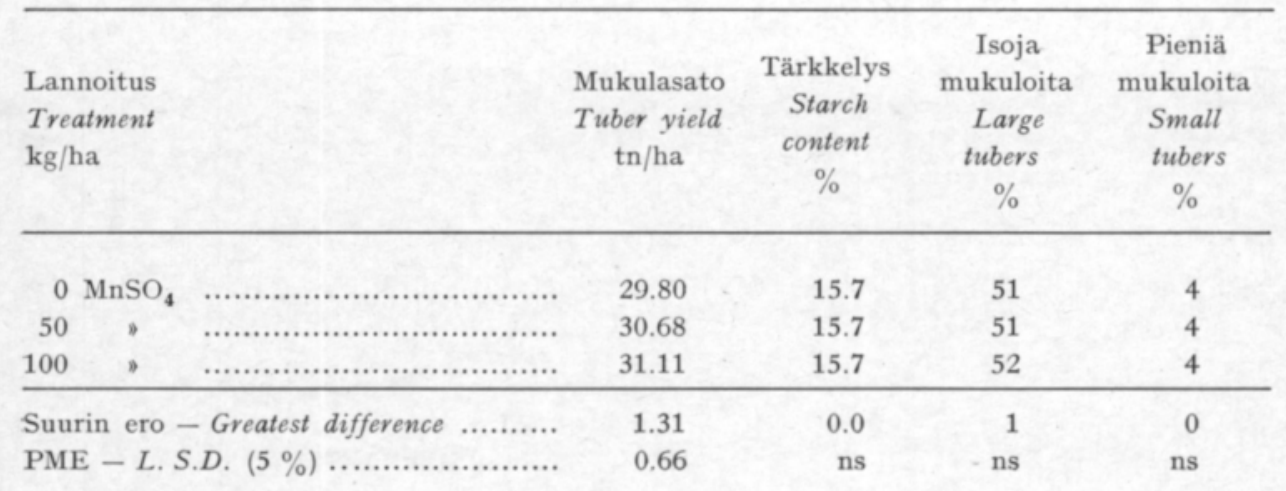

\section{Aineisto 5. NPK-lannoituksen vaikutus 1966-71}

NPK-lannoituskokeiden sadolla perustettiin Anttilaan jälkivaikutuskokeita vuosina 1966-71. NPK-lannoituskokeita on tarkemmin selvitetty aikaisemmissa julkaisuissa (VARIs $1973 \mathrm{a}, 1973 \mathrm{~b}$ ). Näistä kokeista saatu sato eli siis selostetțavissa kokeissa käytetty siemen analysoitiin Satoturve Oy:ssa kuivaaine-, N-, P-, K-, Ca- ja Mg-pitoisuuksien suhteen. Täten pyrittiin selvittämään myös siemenperunan kemiallisen koostumuksen merkitystä sen sadontuottokykyyn. Kokeita oli kaikkiaan 5. Ne järjestettiin vaillinaista lattice-menetelmää käyttäen. Koeruudun koko oli 50 yksilöä, kerranteita oli 2. Lajikkeina olivat kerran Realta ja Amyla, muutoin Pito. Varianssianalyysin tulokset on esitetty Taulukossa 13.

Taulukko 13. Varianssianalyysi NPK-lannoituksen vaikutuksesta siemenperunan sadontuottokykyyn ja sadon laatuun.

Table 13. Analysis of variance of the effects of $N, P$, and $K$ application rates on the yielding capacity of seed potatoes and on the subsequent crop quality.

\begin{tabular}{|c|c|c|c|}
\hline $\begin{array}{l}\text { Tekijä } \\
\text { Factor }\end{array}$ & $\begin{array}{c}\text { Mukulasato } \\
\text { Tuber yield } \\
\text { tn/ha }\end{array}$ & $\begin{array}{c}\text { Tärkkelys } \\
\text { Starch } \\
\text { content } \\
\%\end{array}$ & $\begin{array}{c}\text { Kokojakautuma } \\
\text { Size } \\
\text { distribution } \\
\%\end{array}$ \\
\hline A. Vuosi - Year .................................. & $* * *$ & $* * *$ & $* * *$ \\
\hline 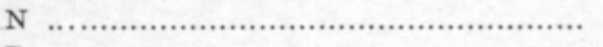 & ** & ns & * \\
\hline P & $* *$ & ns & $(*)$ \\
\hline к & $(*)$ & ns & ns \\
\hline 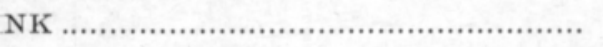 & $* * *$ & ns & ns \\
\hline AP & $(*)$ & ns & $* *$ \\
\hline AK & ns & ns & $(*)$ \\
\hline NP & ns & $* * *$ & ns \\
\hline NK & ns & $(*)$ & ns \\
\hline 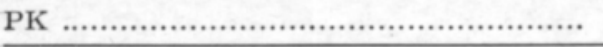 & ns & $*$ & ns \\
\hline
\end{tabular}


Siemenperunan N-lannoitus vaikutti sekä sadon määrään että laatuun (Taulukot 13 ja 14).

Taulukko 14. N-lannoituksen vaikutus siemenperunan sadontuottokykyyn ja sadon laatuun. Table 14. The effects of $N$ application rates on the yielding capacity of seed potatoes and on the subsequent crop quality.

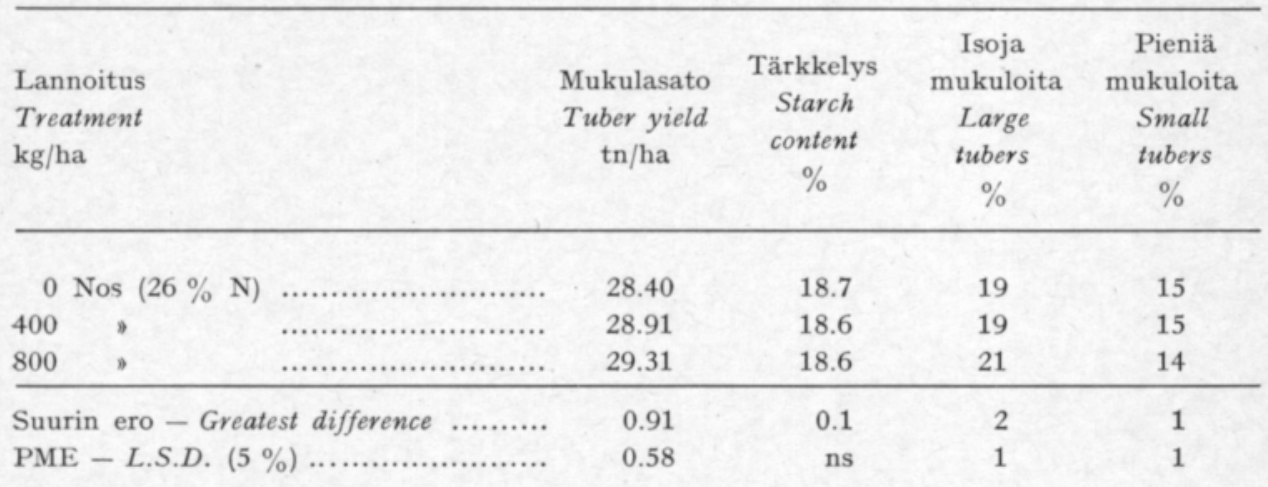

Typpilannoituksen jatkuva satoa lisäävä vaikutus tuli esille joko $0-400$ välillä tai $400-800$ välillä 4 kokeessa (AN).

Taulukko 15. P-lannoituksen vaikutus siemenperunan sadontuottokykyyn ja sadon laatuun. Table 15. The effects of $P$ application rates on the yielding capacity of seed potatoes and on the subsequent crop quality.

\begin{tabular}{|c|c|c|c|c|c|}
\hline $\begin{array}{l}\text { Lannoitus } \\
\text { Treatment } \\
\mathrm{kg} / \mathrm{ha}\end{array}$ & & $\begin{array}{c}\text { Mukulasato } \\
\text { Tuber yield } \\
\text { tn/ha }\end{array}$ & $\begin{array}{c}\text { Tärkkelys } \\
\text { Starch } \\
\text { content } \\
\%\end{array}$ & $\begin{array}{c}\text { Isoja } \\
\text { mukuloita } \\
\text { Large } \\
\text { tubers } \\
\%\end{array}$ & $\begin{array}{c}\text { Pieniä } \\
\text { mukuloita } \\
\text { Small } \\
\text { tubers } \\
\%\end{array}$ \\
\hline 0 Psf $(8.7 \%$ P $)$ & (2) & 28.30 & 18.7 & 19 & 15 \\
\hline 1000 & …........................ & 29.00 & 18.7 & 20 & 15 \\
\hline 2000 & …......................... & 29.31 & 18.7 & 20 & 15 \\
\hline Suurin ero - Greates & ference & 1.01 & 0.0 & 1 & 0 \\
\hline PME - L.S.D. $(5 \%)$ & & 0.58 & ns & 1 & ns \\
\hline
\end{tabular}

Fosforilannoitus lisäsi myös siemenperunan sadontuottokykyä 1.01 tn/ha (Taulukot 13 ja 15). Isojen mukuloiden osuus suureni hiukan.

Kalilannoituksen osalta saatiin paras sato keskimmäisellä määrällä (Taulukot 13 ja 16).

Yhdysvaikutuksista mainittakoon NP-, NK- ja PK-yhdysvaikutukset tärkkelyspitoisuuteen sekä myös NPK-yhdysvaikutus, mitä ei ole esitetty taulukossa 14. Parhaan tärkkelyspitoisuuden tuotți tasapainoitettu lannoitus $\mathrm{N}_{0} \mathrm{P}_{0} \mathrm{~K}_{400}, \quad \mathrm{~N}_{400} \mathrm{P}_{1000} \mathrm{~K}_{400-800}$ tai $\mathrm{N}_{800} \mathrm{P}_{2000} \mathrm{~K}_{400-800} \quad(18.8-18.9)$. Epäsuhtainen lannoitus $\mathrm{N}_{\mathbf{8 0 0}} \mathrm{P}_{\mathbf{0}} \mathrm{K}_{\mathbf{0}}$ alensi tärkkelyspitoisuutța selvästi (18.2). 
Taulukko 16. K-lannoituksen vaikutus siemenperunan sadontuottokykyyn ja sadon laatuun. Table 16. The effects of $K$ application rates on the yielding capacity of seed potatoes and on the subsequent crop quality.

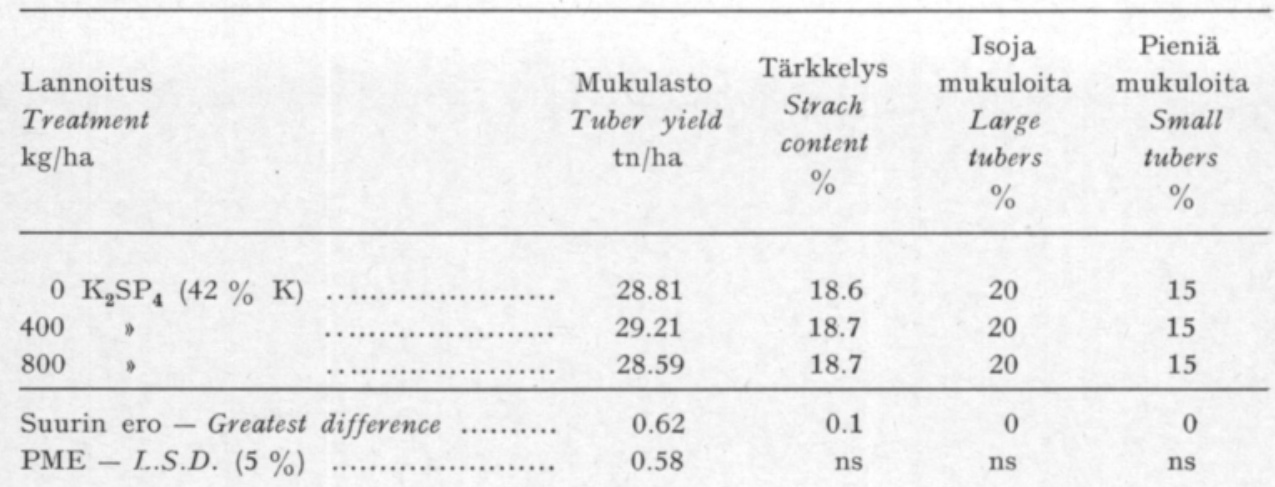

Tästä koesarjasta haluttiin myös tarkemmin selvittää, voitaisiinko siemenperunan kemiallisen koostumuksen perusteella päätellä sen arvoa siemenenä. Käytetystä siemenestä analysoitiin Satoturve Oy:ssä kuiva-aine, N, P, K, $\mathrm{Ca}$ ja $\mathrm{Mg}$.

Mukuloiden analyysitietoja selitțäjinä käyttäen laskettiin multiregressioanalyysit mukulasadolle, tärkkelyspitoisuudelle ja mukulakoolle. Vuosien välinen vaihtelu tasoițettiin $0-1$ muutțujilla. Mukulasadon osalta tulos on esitetty Taulukossa 17.

Taulukko 17. Multiregressioanalyysi siemenperunan kemiallisen koostumuksen vaikutuksesta mukulasatoon.

Table 17. Multiple regression analysis of the effects of the chemical composition of seed tubers on the yielding capacity of seed potatoes.

\begin{tabular}{|c|c|c|c|}
\hline $\begin{array}{l}\text { Selittäjä } \\
\text { Variable }\end{array}$ & b & $\mathbf{r}$ & $\mathrm{R}^{2}{ }_{\text {cumul. }}^{\text {kumul. }}$ \\
\hline Vuosi 1 - Year 1 .......................... & 6.11 & 0.785 & \multirow{4}{*}{0.887} \\
\hline Vuosi 3 - Year 3 ...................... & -5.02 & -0.454 & \\
\hline 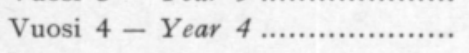 & 3.63 & 0.463 & \\
\hline Vuosi 2 - Year 2 ................... & -1.35 & -0.261 & \\
\hline 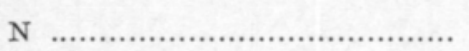 & 2.16 & 0.309 & \multirow[b]{2}{*}{0.903} \\
\hline 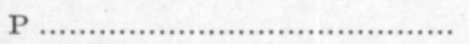 & 12.86 & 0.219 & \\
\hline
\end{tabular}

$\mathrm{K}=22.50$

Satovaihtelun selvitetystä osasta selittivät vuotuiset vaihtelut $98 \%$. Mukulan kemiallisista komponenteista oli merkitystä N- ja P-pițoisuudella. Ne lisäsivät mallin selitysastetta $2 \%$ :lla. Sadon matemaattinen kokonaisvaihtelu $(4 \sigma)$ oli 19.64 țn/ha, mistä mukuloiden kemiallisen koostumuksen osuudeksi tulee $3.14 \mathrm{tn} / \mathrm{ha}$.

Kun malliin lisättiin selittäjäksi kasvuston alkukehitys, nousi $\mathrm{R}^{2} \quad 0.918$ :een, mutta $\mathrm{N}$ ja $\mathrm{P}$ pysyivät edelleen selittäjinä, $\mathrm{N}$ tosin lieventyneenä. 
Taulukko 18. Multiregressioanalyysi siemenperunan kemiallisen koostumuksen vaikutuksesta sadon tärkkelyspitoisuuteen.

Table 18. Multiple regression analysis of the effects of the chemical composition of seed tubers on starch content of the crop.

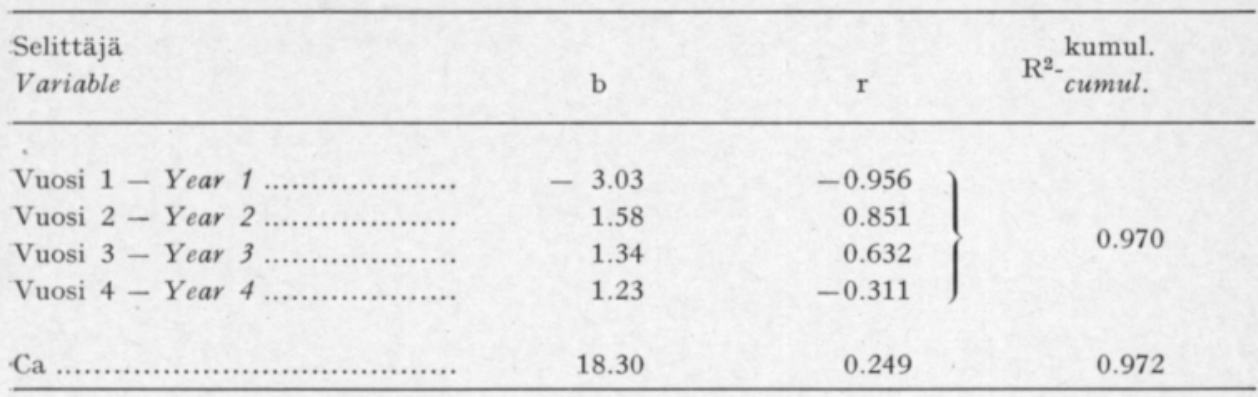

$\mathrm{K}=18.56$

Tärkkelyspitoisuuden vaihtelun selittäjiksi tuli vuosien lisäksi ainoastaan mukuloiden Ca-pitoisuus (Taulukko 18). Sen osuus kokonaisvaihtelusta oli kuitenkin vain $0.2 \%$.

Kasvuston alkukehityshavaintojen lisääminen selittäjäksi ei muuttanut mallia.

Isojen mukuloiden määrän osalta multiregressioanalyysi antoi Taulukossa 19 esitetyn tuloksen.

Taulukko 19. Multiregressioanalyysi siemenperunan kemiallisen koostumuksen vaikutuksesta isojen mukuloiden määrään.

Table 19. Multiple regression analysis of the effects of the chemical composition of seed tubers on the proportion of large tubers in the crop.

\begin{tabular}{|c|c|c|c|}
\hline $\begin{array}{l}\text { Selittäjä } \\
\text { Variable }\end{array}$ & b & $\mathrm{r}$ & $\mathrm{R}^{2}{ }_{\text {cumul. }}^{\text {kumul. }}$ \\
\hline Vuosi 1 - Year 1 .................... & 30.60 & 0.967 & \multirow{3}{*}{0.937} \\
\hline Vuosi $4-$ Year 4 ................... & 18.44 & 0.831 & \\
\hline Vuosi $3-$ Year $3 \ldots \ldots \ldots \ldots \ldots \ldots$ & 20.51 & 0.741 & \\
\hline 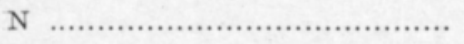 & 2.75 & 0.219 & \multirow[b]{2}{*}{0.942} \\
\hline P & 21.88 & 0.201 & \\
\hline
\end{tabular}

$$
\mathrm{K}=-2.46
$$

Vuosivaihtelun lisäksi tulivat mukaan mukuloiden $\mathrm{N}$ - ja P-pitoisuus, ja näiden osuus kokonaisvaihtelusta, $48 \mathrm{~g}$ :sta, oli $0.5 \%$.

Pienten perunoiden määrästä multiregressioanalyysi antoi Taulukossa 20 esitetyn tuloksen.

Ainoastaan siemenperunoiden kuiva-ainepitoisuudella näytti olevan vuosivaihtelun lisäksi lievä, $0.1 \%: n$, pienten perunoiden määrää lisäävä vaikuțus. Kasvuston alkukehitys ei muuttanut mallia mukuloiden kokojakautuman osalta. 
Taulukko 20. Multiregressioanalyysi siemenperunan kemiallisen koostumuksen vaikutuksesta. pienten perunoiden osuuteen sadossa.

Table 20. Multiple regression analysis of the effects of the chemical composition of seed tubers on the proportion of small tubers in the crop.

\begin{tabular}{|c|c|c|c|}
\hline $\begin{array}{l}\text { Selittäjä } \\
\text { Variable }\end{array}$ & b & $\mathrm{r}$ & $\mathrm{R}^{2-}{ }_{\text {cumul. }}^{\text {kumul. }}$ \\
\hline Vuosi 3 - Year 3 ...................... & 15.9 & -0.939 & \multirow{4}{*}{0.974} \\
\hline Vuosi 1 - Year 1 ....................... & -21.49 & -0.937 & \\
\hline Vuosi 4 - Year 4 ...................... & -18.61 & -0.942 & \\
\hline Vuosi 2 - Year 2 ..................... & -5.16 & -0.735 & \\
\hline K-aine- $\%$ - D.M. $\%$................ & 0.316 & 0.176 & 0.975 \\
\hline
\end{tabular}

$$
\mathrm{K}=20.05
$$

\section{Tulosten tarkastelua}

Kasvuolosuhteiden vaikutuksisța siemenperunan sadontuottokykyyn, on eri maissa suoritetuissa tutkimuksissa saatu vaihtelevia tuloksia. Yhtäpitävästi on kuitenkin todettu, että saman lajikkeen eri siemenerien välillä on olemassa eroja, joita ei voida selittää virus- tai muiden tautien, käsittelyn, varastoinnin tms. syiden seurauksiksi.

Lämpötilan vaikutuksesta on todețtu, että viileässä ilmastossa tuotettu siemenperuna on elinvoimaista ja itujen kehitys nopeaa ja runsasta (vrt. siv. 2). Samoin KozLowsKan $(1960,1963)$ tutkimukset eri korkeusasteilla tuotetusta siemenperunasta osoittivat, että vaikka vuoristossa perunalla oli taipumusta kasvaa kițuliaasti, siellä tuotettu siemen antoi (tasangolla) selvästi parempia satoja kuin tasangolla tuotettu siemen.

Suomen olosuhteissa lämpötilan vaikutus tuli esille Aineistossa 1, missä sekä kasvukauden lämpötilasumman että syyskesän sademäärän nousulla oli negatiivinen vaikutus siemenperunaan. Kun sekä lämpötila etțä sademäärä alenevat pohjoiseen mentäessä, viittaa tulos siemenperunan laadun paranemiseen pohjoiseen siirryttäessä. Ruotsalaisissa tutkimuksissa Pohjois-Ruotsissa tuotettu siemen erosi eteläruotsalaisesta siinä, että se tuotti vähemmän, mutta rehevämpiä versoja. Osittain todettiin myös pieniä satoeroja pohjoisen siemenen eduksi (Svensson 1966, Gustafsson 1972, Hagman 1973). Jos siemenperunan tärkeänä ominaisuutena pidetään runsasta versonmuodostusta, ei pohjoisessa tuotetțu siemen tässä suhteessa ole kuitenkaan parasta mahdollista. Pohjoismaissa todennäköinen vaikuttava tekijä sääolojen lisäksi on leveysasțeeseen liittyvä päivänpituus, millä edellä mainittuja eroja voidaan myös selittää. Päivänpituuden merkitys kaikkine siihen liițtyvine lisätekijöineen on oletettavasti lisäksi yksityistapauksissa erilainen ja riippuvainen mm. lajikkeen ominaisuuksista ja reaktioisța. Merkitystä lienee myös sillä, käytetäänkö tuotettu siemen samalla leveysasteella vai etelämpänä tai pohjoisempana kuin sen tuotantopaikka.

Maaperän vaikutuksista siemenperunaan ovat tutkimustulokset myös vaih- 
televia. Maaperä vaikuttaneekin monimutkaisena sekä mikroilmastollisena että ravinnetekijänä, mistä syystä koepaikan erikoisominaisuuksien mukaan tuloksetkin vaihtelevat. Samoin lajikkeiden reaktiot vaihtelevat (esim. LUNDEN 1950). Monissa tapauksissa näyțtää kuitenkin viileillä typpirikkailla soilla saadun tuottokyvyltään parempaa siemenperunaa kuin hietamailla. Tässä selostetuissa tutkimuksissa ei saatu merkitseviä eroja, joskin suunta oli turvemaan eduksi. VEsIKIVEN (1938) mukaan suomaan siemenen paremmuus johtuisi ainoastaan sadon tuleentumattomuudesta ja että sama vaikutus olisi saavutettavissa muilla maalajeilla varsisto hävittämällä. Voidaan kuitenkin toisaalta olettaa, että turvemaiden runsas typpipitoisuus vaikuttaisi lisätyn typpilannoituksen tavoin ja sitä kautta lisäisi siemenen sadontuottokykyä.

Savimaalla tuotetussa siemenperunassa näyttää olevan taipumusta korkeaan tärkkelyspitoisuuteen, mikä tuli esille sekä tässä että VESIKIVEN (1936) tutkimuksissa.

Maan ravinnepitoisuus ja lannoitus muodostavat ryhmän tekijöitä, joiden merkityksestä on samoin saatu erilaisia tuloksia. Selostetuissa kokeissa todettiin maan hyvän $\mathrm{CaCO}_{3}-$ ja $\mathrm{P}_{2} \mathrm{O}_{5}$-tilan vaikuttavan positiivisesti siemenperunan satoisuuteen, kun taas $\mathrm{pH}: \mathrm{n}$ ja $\mathrm{K}_{2} \mathrm{O}$-tilan vaikutus oli negatiivinen.

Yhtäpitäväsți muiden tutkimusten kanssa näyttää siis kalsiumin ja fosforin vaikutus suotuisalta, kaliumin runsaana määränä haitalliselta. Multiregressioanalyysi osoitti myös $\mathrm{pH}: n$ sinänsä olevan lievästi haitallinen, joskin sen korreloituminen kalsiumiin kumoaa molempien vaikutusta.

Typpi- ja fosforilannoituksen suhteen selostettavat tutkimukset osoittivat, kuten edellä on jo tuotu esille, yleensä positiivista vaikutusta. Aineistosta $\mathbf{5}$ voidaan lisäksi päätellä, että siemenperunan typpilannoituksen optimi oli suurempi kuin ruoka- tai tärkkelysperunan (vrt. VARIS 1973).

Typpi- ja fosforilannoituksella aikaansaadulla mukuloiden N- ja P-pitoisuuden nousulla näytti olevan siemenperunan tuottokykyyn edullinen vaikutus. Näiden vaikutus perustui kuitenkin mukulakoon suurenemiseen, kuten myös Schepers ym. (1969) ja Gustafsson (1972) totesivat typen osalta. Typen ja fosforin edullinen vaikutus ei siten johtuisi itujen eikä mukuloiden määrän lisääntymisestä, vaan todennäköisesti nopeamman alkukehityksen aiheuttamasta mukuloiden nopeutuneesta lisäkasvusta.

Pääravinteiden lisäksi todettiin myös magnesium- ja mangaanilannoituksen pystyvän lisäämään siemenperunan tuottokykyä. Voitaneekin olettaa, että yleensä sivu- ja hivenravinteiden puute, mikä vaikuttaa itse siemenperunan satoon, heijastuu myös siemenperunan sadontuottokyvyssä.

Siemenperunan käyttöarvoa määräävinä tekijöinä kasvuolosuhteiden vaikutuksilla ei ole kokonaisuudessaan, muutamia poikkeuksellisia olosuhteita lukuunottamatta, ratkaisevaa merkitystä. Niillä on merkitystä vasta silloin kun muut siemenen sadontuottokykyyn vaikuttavat tekijät, ennen kaikkea terveys ja käsittely, ovat kunnossa.

\section{Yhteenveto}

Hankkijan kasvinjalostuslaitoksella tutkittiin 1960-luvulla usein eri aineistoin kasvutekijöiden vaikutusta siemenperunan käyttöarvoon. 
Kasvuolosuhteiden vaikutus oli pieni verrattuna lajikkeiden välisiin satoeroihin ja virustautien vaikutukseen.

Maalajeista olivat turvemaa ja multava savi hietamaata parempia kasvualustoja.

Maaperän korkea Ca- ja P-pitoisuus vaikuttivat edullisesti siemenen sadontuottokykyyn, pH:n ja K-pitoisuuden vaikutus oli negatiivinen. Lämpösumma ja syyskuun sademäärä korreloituivat negatiivisesti țärkkelyspitoisuuteen, leveysaste vaihtoehtoisena selittäjänä positiivisesti. Siemenen tärkkelyspitojsuus vaikutti hyvin lievästi positiivisesti sekä mukulasatoon että tärkkelyspitoisuuteen.

Korjuuajan vaikutus ei ollut merkitsevä, joskin suunta oli aikaisen korjuun eduksi.

Ravinteista oli positiivinen vaikutus typellä, fosforilla, magnesiumilla ja mangaanilla. Kaliumin vaikutus oli vaihteleva ja riippui käytetystä määrästä. Kalsiumilla ei ollut merkitseviä vaikutuksia.

Siemenmukuloiden tärkkelyspitoisuus vaikutti edullisesti sekä satoon että tärkkelyspitoisuuteen. Mukuloiden N- ja P-pitoisuus selittivät merkitsevästi siemenerien välisiä satoeroja. Mukuloiden Ca-pitoisuus vaikutti positiivisesti tärkkelyspitoisuuteen.

\section{KIRJALLISUUTTA}

Alten, F., Breyhan, T., Fischnich, H., Heiliger, F., Hofmann, E., latzko, E. \& Pätzold C. 1960. Stoffwechselphysiologie und Vitalität von Pflanzkartoffeln. Landw. Forsch. 14: $97-107$.

Bocz, E. 1965. Beiträge zum ökologischen Abbau der Kartoffel. O Degeneraci brambor: 95-101. Východočeská Nakladatelstvi.

Brandt, J. \& Sessous, D. 1953. Bedeutung der Phosphorsäuredüngung für Leistung und Gesundheit der Kartoffel. Phosphorsäure 13: 293-311.

Cochran, W. G. \& Cox, G. M. 1960. Experimental Designs. 601 p. New York.

DENsch, M. 1930. The influence of phosphoric acid on the productivity of seed potatoes. Superphosphate 3: 286-289.

Fischnıch, O. \& Pätzold, C. 1961. Die Bedeutung der Phosphatdüngung für die Pflanzkartoffelerzeugung. Z. Pflernähr., Düng., Bodenk. 93: 214-220.

Fleischel, H. 1957. Phosphatdüngung zu Kartoffeln. Kartoffelbau 8:4-5.

GERICKE, S. 1960. Phosphatdüngung im Kartoffelbau. Kartoffelbau 11: 11-12.

Gustafsson, N. 1972. Jämförelse mellan utsädeshärstamningar från olika breddgrader. MarkVäxter 16: 19-20.

Hagman, C-G. 1973. Quality of seed potatoes - properties and relationships. Lantbr.högsk. $82 \mathrm{p}$.

Hofferbert, W. 1954. Gesunde hochwertige Pflanzkartoffeln. Kartoffelbau 5:4.

- - \& Putlitz, G. 1956. Kann man durch mineralische Düngung den Nachbauwert der Kartoffeln beeinflussen. Kartoffelbau 7:112-115.

IRITANI, W. M. 1967. Some factors affecting productivity of Russet Burbank seed potatoes. Amer. Potato J. 44: 153-158.

KLAPP, E. 1930. Kartoffel und Standort. Pflanzenbau 7: 138-146.

- - 1936. Zusammenhänge von Standorteigenschaften, Viruserkrankung und Nachbauertrag der Kartoffel. Pflanzenbau 12: 162-191.

- - 1951. Zusammenhang düngungs- und bodenbedingter Standortunterschiede mit Pfirschblattlausbesatz und Nachbauwert der Kartoffel. Z. Acker-Pflbau 93: 347-358. 
Kozlowsкa, A. 1960. Effects of environment on tuber production, potassium absorption and susceptibility of potatoes to virus diseases in Poland. Amer. Potato J. 37: 366-373.

- -1963 . Differences in growth and metabolism of potatoes grown in the mountains and lowlands. Eur. Potato J. 6: 143-159.

KrÜGER, F. H. 1951, Ưber den Einfluss einseitiger Düngung auf den Kartoffelabbau. Z. Acker-Pflbau 93: 359-385.

Lunden, A. 1950. Forsøk med settepoteter fra forskjellig jordart. Nor. Landbr.høgsk. Meld. 140: $445-476$.

Osvald, H. 1929. Utsädesväxlingens betydelse vid potatisodling. Sv. Mossk. För. Tidskr. 43: $93-118$.

Pfeffer, C. 1956. Untersuchungen über den Wert der in verschiedenen Gebieten erzeugten Pflanzkartoffeln. Züchter 26: 257-269.

- - 1959. Über den Einfluss der Düngung auf den Pflanzgutwert von Kartoffeln. Eur. Potato J. 2: 238-250.

Salohermo, L. 1934. Perunan viljelemisestä suolla Keski-Suomessa. Suom. Suovilj.yhd. Vuosik. 38: 122-147.

Schepers, A., Hoogland, R. F. \& Krijthe, N. 1969. Influence of NPK-application to seed potato crops on the productivity of the progeny. Eur. Potato J. 12: 251-263.

SchoENE, G. 1937. Versuche über Phosphorsäuredüngung zur Erzeugung von Saatkartoffeln. Pflanzenbau 13: 94-105.

Stottmeister, W. 1958. Die Beziehungen zwischen Knollenertrag und Bodenart des Herkunftsortes. Deut. Landw. 9: 374-376.

Svensson, B. 1966. Seed tuber - stand - yield. Publ. Dept. Pl. Husb. Agric. Coll. Sweden 21: $1-86$.

UlRich, G., Neitzel, K. \& Scholz, M. 1963. Untersuchungen zum Kartoffelbau unter trockenen und warmen Anbaubedingungen der Südukraine. Eur. Potato J. 6: 227-239.

VARIS, E. 1970. Variation in the quality of table potato and the factors influencing it in Finland. Acta Agr. Fenn. 118, 3: 1-99.

- 1973 a. The effects of increasing NPK rates on the yield and quality of the Pito potato. Acta Agr. Fenn. 128, 1: 3-23.

- -1973 b. NPK-lannoituksen vaikutus perunoiden kemialliseen koostumukseen. J. Scient. Agric. Soc. Finl. 45: 468-481.

Vesıkıvi, A. 1936. Suomen Suoviljelysyhdistyksen koeasemien v:n 1935 koetuloksia. Suom. Suovilj.yhd. Vuosik. 40: 56-74.

_ - 1938. Suomen Suoviljelysyhdistyksen koeasemien v:n 1937 koetuloksia. Suom. Suovilj.yhd. Vuosik. 42: 4-66.

- -1939 . Suomen Suoviljelysyhdistyksen koeasemien v:n 1938 koetuloksia. Suom. Suovilj.yhd. Vuosik. 43: 44-72.

VoGT, W. 1953. Düngungsversuchsergebnisse an der Saatguterzeugergemeinschaft Hannover. Kartoffelbau 4: 10.

Volkart, A. 1948. Der Einfluss steigender Stickstoffgaben auf den Saatgutwert der Kartoffeln. Landw. J.buch. Schweiz 62: 89-95.

WENT, F. W. 1959. Effect of environment of parent and grandparent generation on tuber production by potatoes. Amer. J. Botany 46: 277-282.

Wenzl, H. \& Demel, J. 1952. Untersuchungen über den Pflanzgutwert fadenkeimiger Kartoffelknollen. Bodenkultur 6:41-54.

Witte, H. 1923. Potatisodling på torvjord, dess möjligheter och förutsättningar. Sv. Mossk. För. Tidskr. 37: 4-36.

Wünscher, C. 1953. Ưber den Einfluss der Düngung auf Leistung und Gesundheit der Kartoffel. Z. Acker-Pflbau 94: 377-421.

Zogg, H., Horber, E. \& Salzmann, R. 1949. 8. Pflanzenschutz. Landw. J.buch Schweiz $63: 383-395$. 